\title{
EXPRESSION OF AMINO ACID DECARBOXYLASE IN PROLIFERATING CELLS OF THE NEURAL TUBE AND NOTOCHORD OF DEVELOPING RAT EMBRYO ${ }^{1}$
}

\author{
GLADYS TEITELMAN, ${ }^{2}$ CHRISTINE B. JAEGER, VIVIAN ALBERT, TONG H. JOH, AND \\ DONALD J. REIS
}

Laboratory of Neurobiology, Cornell University Medical College, New York, New York 10021

Received September 14, 1982; Revised January 21, 1983; Accepted January 31, 1983

\begin{abstract}
In vertebrate embryos, the catecholamine (CA) neurons of brain and periphery arise from undifferentiated precursors in the ventral neural tube and neural crest to migrate to their final location where they first express tyrosine hydroxylase (TH). We sought to determine by immunocytochemistry and autoradiography whether the next enzyme of the CA pathway, aromatic L-amino acid decarboxylase (AADC) (1) is expressed by CA precursors before or, as TH, after reaching their final site and (2) is present in proliferating cells.

AADC was first observed on day 12 of development (E 12) in all cells of the notochord along its entire length and in neuroepithelial cells of the ventral neural tube from the mesencephalic to the lumbar region. At E 14 the cells of the sacral basal plate of the neural tube also contained AADC. At this stage, some cells of the notochord and neural tube containing AADC were also labeled with tritiated thymidine. At E 16 the cells of the notochord lacked AADC immunoreactivity, and at E 21 the enzyme was no longer detected in the ventricular layer of the developing brain. At this stage and in the adult stage, however, a few cells containing AADC were found scattered in the spinal cord. AADC was not detected in migrating neural crest cells. The studies indicate that in rat embryo: (1) AADC is expressed by cells of the ventral neural tube and notochord from $\mathrm{F} 12$ until late gestation; (2) the onset of expression of AADC occurs prior to the last cell division; and (3) at least in brain, the precursors of CA neurons express AADC while still in their site of origin and $\mathrm{TH}$ after arriving at their final location.
\end{abstract}

During early vertebrate development, cells which in adults populate the autonomic or central nervous system and synthesize and store catecholamines (CAs), arise from precursor cells localized, respectively, in neural crest or the ventricular layer of neural tube. These cellular precursors contain neither CAs nor tyrosine hydroxylase (TH), the first enzyme of the CA-biosynthetic pathway and hence have yet to express their CA phenotype. It is only after the undifferentiated precursor cells leave their tissue of origin to emigrate either from neural crest into the sympathetic ganglia or from the ventricular to intermediate (mantle) layer of brain that TH and the capacity to synthesize and store CAs are expressed (Enemar et al., 1965; Olson and Sieger, 1972; Golden, 1973; Lauder and

\footnotetext{
${ }^{1}$ We express appreciation for the excellent technical assistance of Leila Grayson. This research was supported by Research Grant HL18974 and Training Grant HL07379 from the National Heart, Lung and Blood Insititue.

${ }^{2}$ To whom correspondence should be addressed.
}

Bloom, 1974; Cochard et al., 1978; Teitelman et al., 1978, 1979; Specht et al., 1981).

It is therefore, paradoxical that administration into chick embryos of the CA precursor L-DOPA results, in advance of the appearance of CA neurons, in specific CA histofluorescence in neuroepithelial cells of the ventral neural tube, cells of the underlying notochord, and cells presumed to be of neural crest origin (Pearse and Polak, 1971; Kirby and Gilmore, 1972; Laurence and Burden, 1973; Allan and Newgreen, 1977). Because L-DOPA itself does not fluoresce, these findings imply that it must be first converted to a CA product, dopamine (DA) or conceivably norepinephrine or even epinephrine. The major route of conversion of L-DOPA in CA cells is by decarboxylation to dopamine by the second enzyme of the CA biosynthetic pathway, aromatic L-amino acid decarboxylase (AADC). Thus the production of CA fluorescence after administration of L-DOPA in precursor tissues suggests either: (1) that AADC is first expressed in CA precursor cells of brain and periphery prior to their 
emigration and expression of the specific CA biosynthetic enzyme TH; or (2) that L-DOPA is converted by L-AADC elsewhere in the embryo to a fluorescent amine which is then taken up and stored in notochord and progenitor cells of CA neurons of brain and neural crest. Because in brain the germinal ventricular layer is the site of neuronal genesis (Sidman and Miale, 1959; Hanaway et al., 1971; Lauder and Bloom, 1974), the presence of AADC cells in this location would suggest that, unlike TH, AADC is expressed by brain cells which are still proliferating.

In the present study, the availability of highly specific antibodies against AADC, purified from bovine adrenal medulla, has allowed us to determine by immunocytochemistry in rat embryo: (1) the time of appearance of AADC in cells of the peripheral and central nervous system, and, by combining immunocytochemistry and autoradiography, (2) whether the cells containing AADC in the central nervous system still divide.

\section{Materials and Methods}

Pregnant Sprague-Dawley rats were received after the first week of gestation and housed individually. The first day of pregnancy was dated as the day of appearance of the vaginal plug. At an appropriate day of gestation, pregnant females were anesthetized with pentobarbitol (40 $\mathrm{mg} / \mathrm{kg}$, i.p.) and the embryos removed and fixed for $2 \mathrm{hr}$ in $4 \%$ formaldehyde in $0.1 \mathrm{M}$ phosphate buffer. Newborn and adult rats were anesthetized and perfused through the heart with formalin/sodium phosphate for 5 min, and the tissues were removed and postfixed in cold formalin for $1 \mathrm{hr}$. The fixed tissues were infiltrated with $30 \%$ sucrose overnight, and the following day were sectioned at $16 \mu \mathrm{m}$ in a cryostat microtome. Sections were consecutively incubated with: (1) rabbit antibody against bovine AADC (1:500 dilution in $0.2 \mathrm{M}$ Tris saline plus $1 \%$ goat serum); (2) goat anti-rabbit IgG (1:50 dilution in 0.2 M Tris saline plus $1 \%$ goat serum); and (3) peroxidaseantiperoxidase (PAP) complex (1:100 dilution in $0.2 \mathrm{M}$ Tris saline plus $1 \%$ goat serum) as previously described (Teitelman et al., 1979). The bound peroxidase was visualized by incubating the sections with $0.013 \% 3,3^{\prime \prime}$-diaminobenzidine (DAB, Sigma) and $0.01 \%$ hydrogen peroxidase (30\% solution) (Sternberger et al., 1970). The sections were then dehydrated, mounted in Permount, and photographed using Nomarski interference optics.

Source of antibodies. In order to produce antibodies to AADC, the enzyme was purified from fresh bovine adrenal medulla essentially as described by Christenson et al. (1970). In brief, fresh bovine adrenal medulla was homogenized in $10 \mathrm{~mm}$ potassium phosphate buffer, $\mathrm{pH}$ 7.4 , containing $1 \mathrm{~mm}$ dithiothreitol, and the homogenate was centrifuged al $100,000 \times g$ for $60 \mathrm{~min}$. The supernatant was collected, and the protein in the supernatant was fractionated between 30 and $45 \%$ saturation of ammonium sulfate. The protein was suspended in the homogenizing buffer and dialyzed against the same buffer. The enzyme was further purified by the following sequential column chromatographic separation: DEAE-cellulose, Sephadex G-200, and hydroxyapatite. The final product was then subjected to polyacrylamide gel electrophoresis, and the enzymatically active protein band was identified by assaying gel slices. Gel slices which contained enzymatically active protein were collected, homogenized with $0.9 \%$ saline, mixed with complete Freund's adjuvant, and injected subcutaneously into rabbits. Four injections with a 2 -week interval were required to produce high titer antisera.

Antibodies were determined to be specific for AADC by their ability to precipitate AADC activity from a crude preparation of enzyme and the production of a single immunoprecipitin arc when analyzed by immunodiffusion and immunoelectrophoresis against a crude antigen preparation. In addition to these tests, the highly sensitive technique of Western blotting was used to establish antibody specificity. Rat brain and adrenal homogenates, fractionated between 30 and $45 \%$ saturation of ammonium sulfate, were subjected to SDS-polyacrylamide gel electrophoresis (Laemmli, 1970) and transferred to nitrocellulose according to the method of Towbin et al. (1979). Nonspecific sites on the nitrocellulose were blocked with $1 \%$ gelatin, and blots were stained with a $1: 1000$ dilution of antibody overnight at $4^{\circ} \mathrm{C}$, rinsed throughly, and then incubated with a $1: 200$ dilution of goat anti-rabbit conjugated horseradish peroxidase. Visualization of antigen-antibody complexes with 3,3, diaminobenzidine revealed a single band of approximately 57,000 daltons (Fig. 1) corresponding to the molecular weight of AADC. A single protein band of 57,000 daltons was also observed when homogenates of rat kidney and liver were used for Western blotting as described above (V. Albert, D. J. Reis, and T. H. Joh, manuscript in preparation). Because this technique will reveal extremcly minor contaminant proteins which might react with the antibody, we have judged this antibody to be highly specific for AADC.

Autoradiography. The techniques used for simultaneous location of $\left[{ }^{3} \mathrm{H}\right]$ thymidine label and immunoperoxidase staining are described elsewhere (Rothman et al. 1980). In brief, pregnant rats were injected (i.p.) with 5 $\mu \mathrm{Ci} / \mathrm{gm}$ of $\left[{ }^{3} \mathrm{H}\right]$ thymidine in $1.2 \mathrm{ml}$ of vehicle (specific activity $54.8 \mathrm{Ci} / \mathrm{nmol}$, New England Nuclear) during the 14 th day of gestation. The animals were killed $2 \mathrm{hr}$ after the injection, and the embryos were removed, fixed, sectioned, and processed for the location of AADC. After the location of the $\mathrm{PAP}$ complex by the $\mathrm{DAB}$ reaction, the sections were washed several times with distilled water, coated with Kodak NTB2 emulsion (diluted 1:2 in water), dried, and exposed for 1 to 2 weeks at $4^{\circ}$ in a light-tight box containing a desiccant. The slides were then developed, fixed, washed, dehydrated, and mounted in Permount.

\section{Results}

Appearance of $A A D C$ in cells of the central nervous system and notochord. AADC was first observed on day 12 of development (E 12) in notochord and neural tube (Fig. 2). The enzyme was present in almost all cells of the notochord, from its apical end in the mesencephalic region of the brain (Fig. $2 C$ ) to its sacral terminus (Fig. $2, A$ and $B$ ). In neural tube, AADC was present in most neuroepithelial cells of the basal plate, from the developing mesencephalon (Fig. $2 C$ ) to the lumbar region (Fig. $2 A$ ). It was not, however, detectable caudally in cells of the sacral basal plate (Fig. $2 B$ ). 


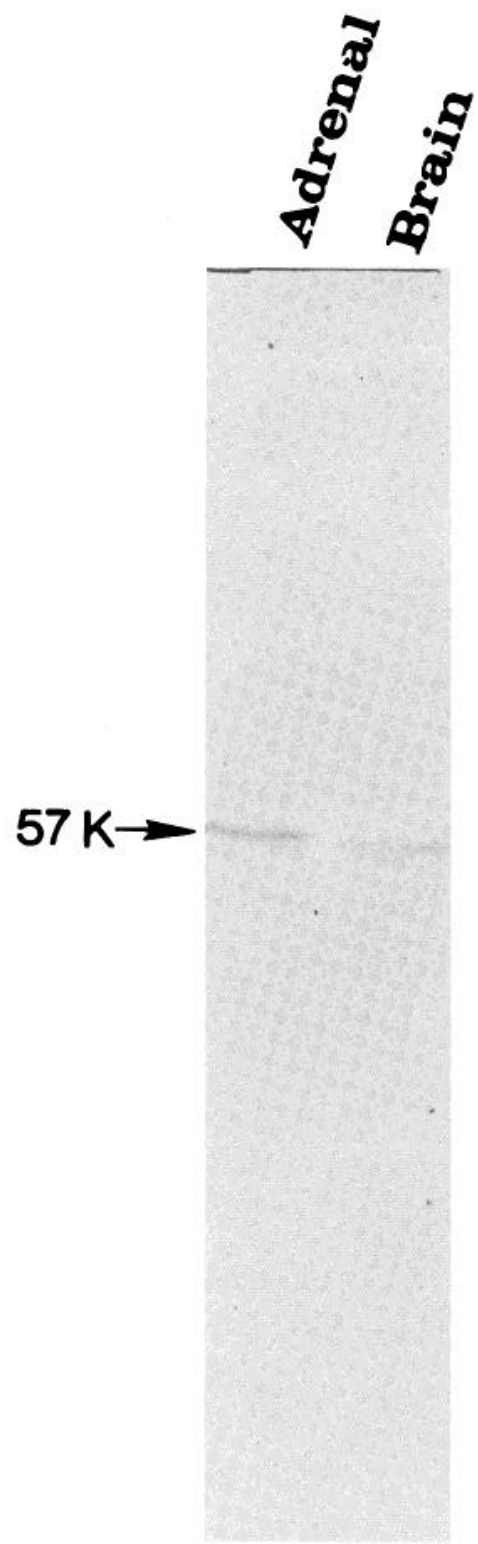

Figure 1. Western blot: Crude preparations of AADC from rat brain and adrenal were separated by SDS-polyacrylamide gel electrophoresis, transferred to nitrocellulose, and stained with anti-AADC as described under "Materials and Methods." Note the single band of reaction product at 57,000 daltons.

By E 14, AADC, still present in the notochord (Fig. $2 D$ ), was detectable along the neural tube, including the sacral portion (Fig. $2 D$ ). At E 16, AADC could no longer be detected in the notochord. The enzyme, however, was still present in cells of the ventrolateral margin of the basal plate of spinal cord and brain (Fig. 3, $A$ and $B$ ) but had disappeared from cells of the floor plate (Fig. 3, $A$ and $B$ ). At this stage, cells containing AADC were observed for the first time in neurons which, by their location, could be regarded as primordia of monoaminergic nuclei groups of brain (Fig. $3 B$ ).

At E 21, just before birth, AADC was no longer detectable in cells of the ventricular layer of brain but was confined to the ever-increasing number of cells in monoaminergic brain nuclei wherein the intensity of immu- nostaining was substantially increased, in comparison to that detectable at earlier stages (Fig. 4). In this latter stage and in adults, the intensity of the immunohistochemical reaction was less in cells of the nucleus locus ceruleus than in those of other monoaminergic groups (Fig. 4, $A$ and $C$ ). This difference in staining intensity was not observed in the adjacent sections which were labeled with TH antibodies (Fig. $4, B$ and $D$ ). In the spinal cord of newborn and adults, fibers and, occasionally, cells containing AADC were seen in the periventricular region along its entire length (Fig. 5).

Appearance of $A A D C$ in peripheral tissues. At E 11, $\mathrm{TH}$ and dopamine $\beta$-hydroxylase (DBH) first appear in sympathetic ganglia (Cochard et al., 1978; Teitelman et al., 1978, 1979). However, at that time AADC was never seen in cells of the neural crest nor of any peripheral tissues. On E 14, AADC was first detectable in sympathetic ganglion cells (Fig. 6A). By E 16, AADC appeared in cells of the adrenal medulla, coincident with the first appearance of TH and DBH (Fig. $6 B$ ). Interestingly, in contrast to mouse, pancreatic islets of rat embryos and adults never contained AADC (Teitelman et al., 1981a, b). The enzyme, however, was found in the thyroid gland of newborn and adult mice and rats, in a perifollicular distribution similar to that of the calcitonin cells.

Proliferation of $A A D C$-containing cells. We sought to determine if cells proliferate after expressing AADC. $\left[{ }^{3} \mathrm{H}\right]$ Thymidine was injected on E 14 into embryos which were killed $2 \mathrm{hr}$ later and processed for combined immunohistochemistry and autoradiography.

In brain (Fig. 7), some neuroepithelial cells of the basal plate were doubly labeled with AADC, immunostained in the cytoplasm, and silver grains localized over the nucleus. Some doubly labeled cells were adjacent to the lumen of the ventricle and thus probably were in mitosis. Others lay deeper in the neuroepithelium and were probably in other phases of the cell cycle (Sidman and Miale, 1959). In contrast to the basal plate where few cells had incorporated $\left[{ }^{3} \mathrm{H}\right]$ thymidine into their nuclei, a high proportion of cells of the alar plate (which lacks AADC) contained silver grains over their nuclei. Cells containing both AADC and $\left[{ }^{3} \mathrm{H}\right]$ thymidine were also found in the sympathetic ganglia and the notochord. Thus, cells containing AADC in ventricular layer of brain and in periphery proliferate after expressing the enzyme.

\section{Discussion}

In this study, we sought to determine immunohistochemically the time of appearance of AADC in cells of the peripheral and central nervous system of rat. In particular, we sought to establish whether AADC was expressed by cells of the germinal ventricular layer of the neural tube and by migrating neural crest cells. We found that AADC was first seen at E 12 in neuroepithelial cells of the ventral neural tube and in cells of the notochord. The fact that CA histofluorescence can be detected in these same sites after administration of L-DOPA (Kirby and Gilmore, 1972; Laurence and Burden, 1973; Allan and Newgreen, 1977) suggests that AADC is enzymatically active.

The appearance of AADC in neural tube follows an apico-caudal gradient: at E 12, the enzyme is seen in cells 

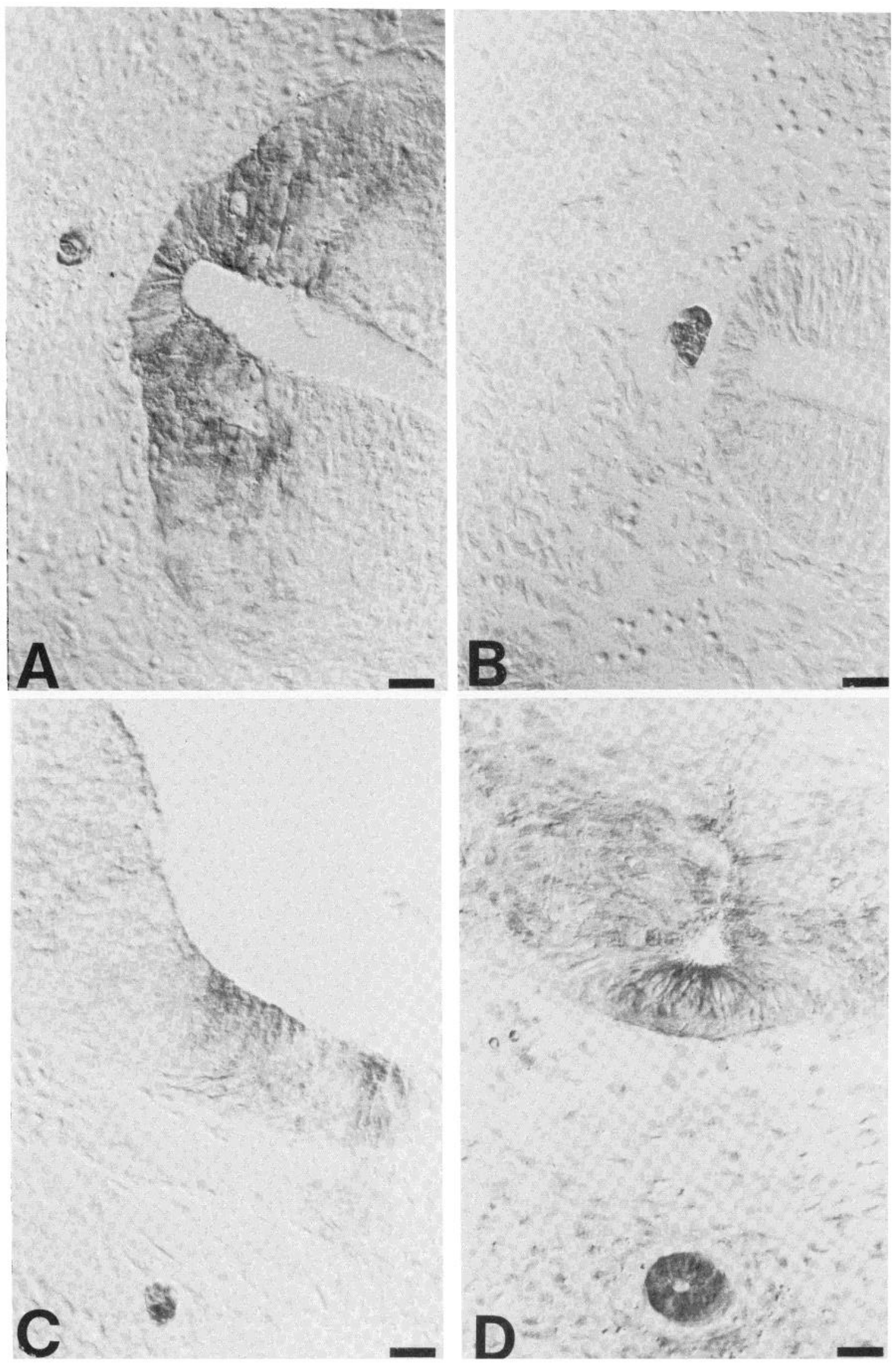

Figure 2. Immunocytochemical localization of AADC in cross-section of rat embryo by the PAP technique. $A$ to $C$, Day 12 of development. $A$, Lumbar region; $B$, sacral region; $C$, mesencephalon; $D$, day 14 of development, sacral region. $B a r=20 \mu \mathrm{m}$. 

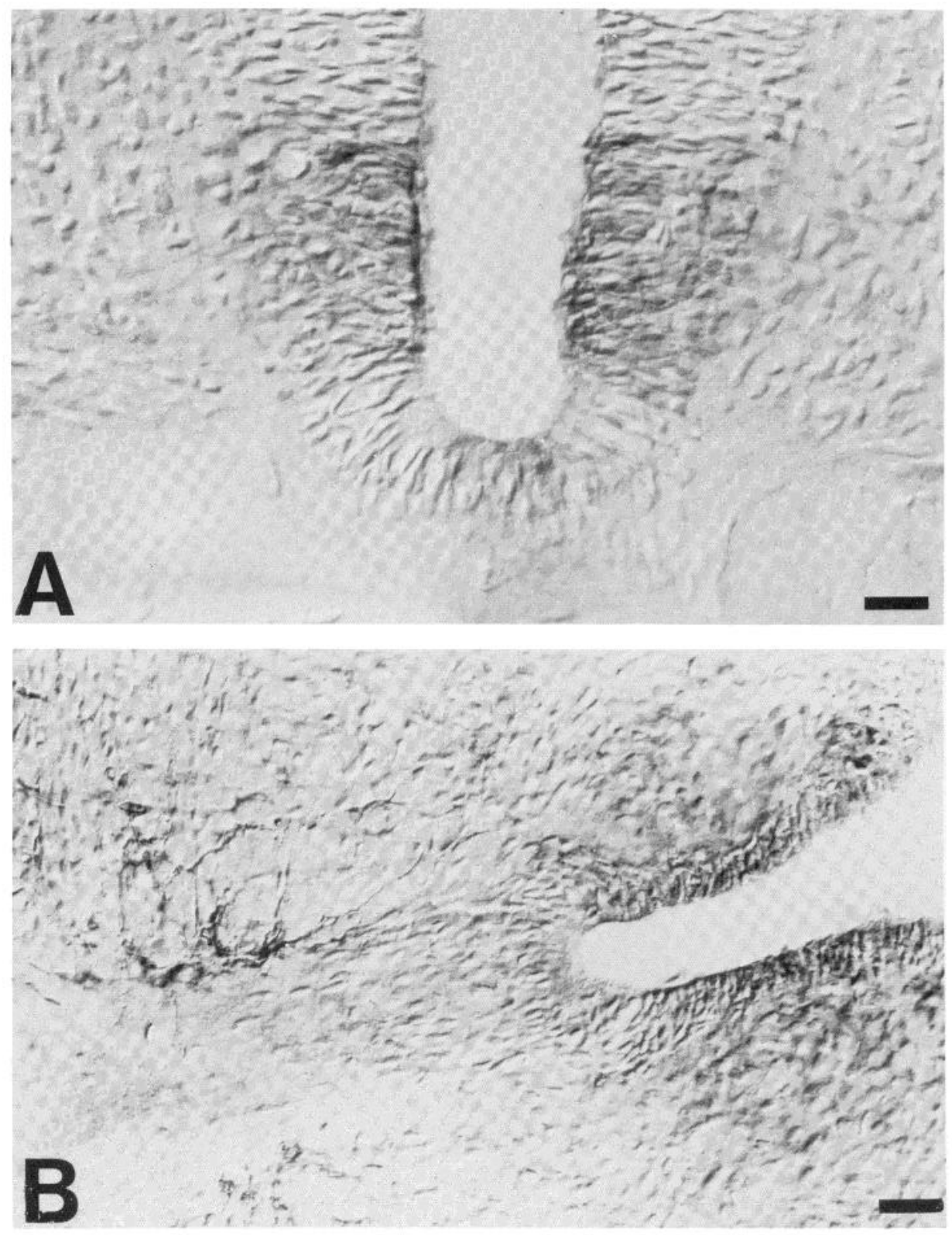

Figure 3. Immunocytochemical localization of AADC in cross-section of rat embryo at day 16 of development. $A$, spinal cord, lumbar region. $B a r=20 \mu \mathrm{m} . B$, Hindbrain. Bar $=40 \mu \mathrm{m}$.

of the mid- and hindbrain and thoracolumbar spinal cord. However, it is not seen in the sacral region until 2 days later, at $\mathrm{E} 14$. In contrast, at $\mathrm{E} 12 \mathrm{AADC}$ is present in the notochord along its entire length, including its sacral terminus.

The fact that in brain most cells of the ventral half of the neural tube express AADC from $\mathrm{E} 12$ to $\mathrm{E} 16$, a time when neuroblasts in the region are giving rise to the CA and 5-HT nuclear groups (Hanaway et al., 1971; Lauder and Bloom, 1974), strongly suggests that at least some of the neuroepithelial cells containing the enzyme are, themselves, precursors of monoaminergic neurons. The observation that AADC is present in cells of the ventricular layer whereas TH (Specht et al., 1981) and endogenous serotonin (Lauder et al., 1981) are restricted to cells already present in the mantle (intermediate) layer further suggests that, in monoamine neurons, AADC may be the first enzyme of monoamine biosynthesis to appear.
Moreover, the fact that cells in the ventricular layer containing AADC still incorporate $\left[{ }^{3} \mathrm{H}\right]$ thymidine indicates that, after expressing the enzyme, the cells continue to proliferate. Thus, after the cells with L-AADC migrate from the ventricular to the intermediate layer, it is likely that they undergo two further maturational changes. First, they become postmitotic and second, they express their constituent specific biosynthetic enzymes TH (Rothman et al., 1980), and most probably, tryptophan hydroxylase (because endogenous serotonin can be detected at this time). During this transition from the ventricular to the intermediate layer, the content of AADC is probably reduced since the enzyme is seen at $\mathrm{E}$ 12 in neuroepithelial cells whereas it is observed in postmitotic neurons of the intermediate layer 4 days later, at E 16.

Although it is likely that some neuroepithelial cells of the mid- and hindbrain containing AADC give rise to 
monoaminergic brain nuclei, the fate of other AADCcontaining cells, particularly those of the spinal cord, is intriguing, because monoamine neurons are not seen in rat in this location (Dahlstrom and Fuxe, 1965). Conceivably, the expression of AADC in some of these cells may be transient, like the expression of $\mathrm{TH}$ in some cells of
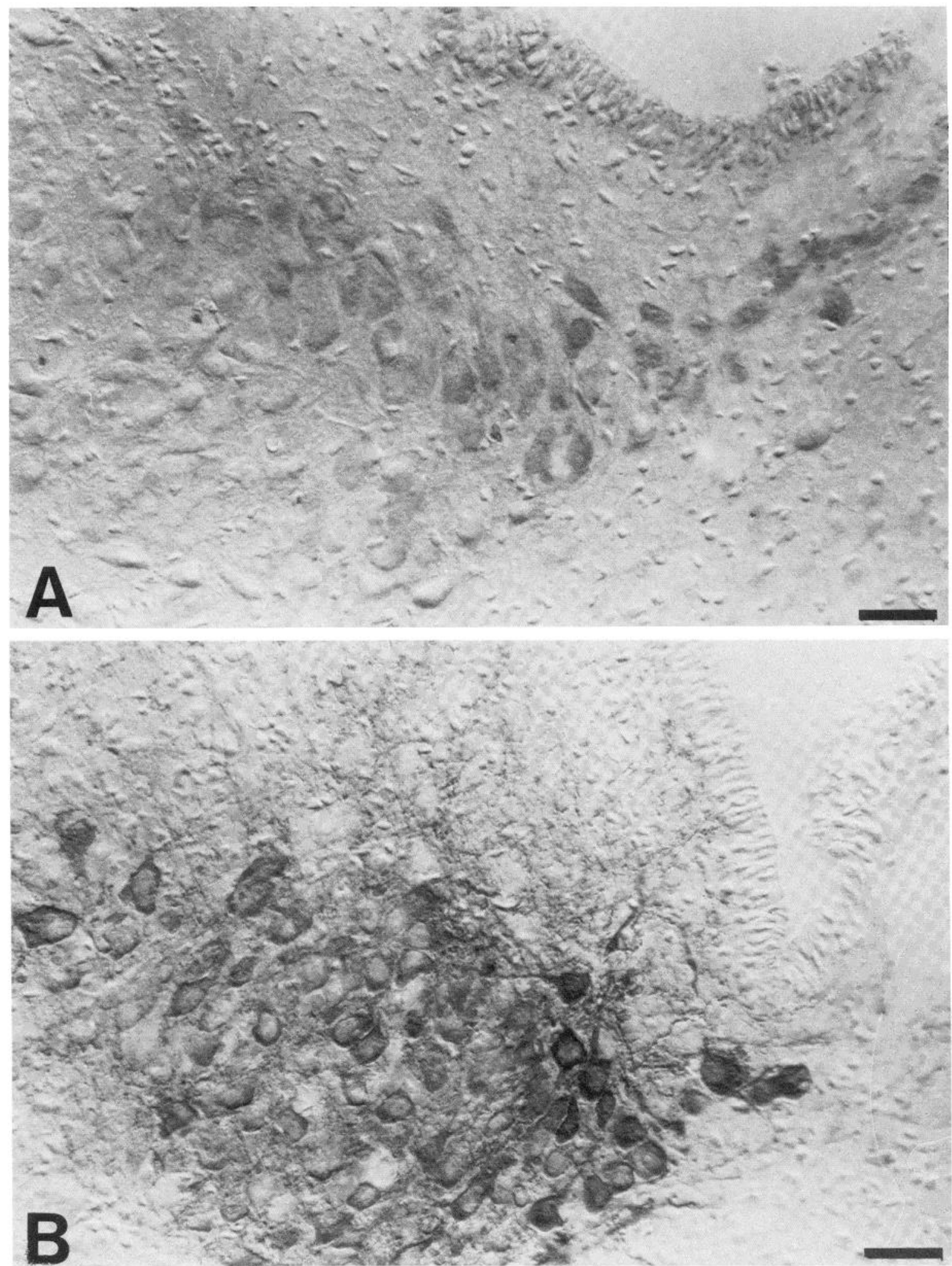

Figure 4. Immunoperoxidase localization of AADC in catecholaminergic nuclei of rat brain at day 21 of development. Consecutive sections stained with antibodies against TH are shown for comparison. Locus ceruleus: $A$ (AADC) and $B$ (TH). A-5 nucleus: $C$ (AADC) and $D(\mathrm{TH})$. Note that the cells of the nucleus locus ceruleus display faint AADC immunoreactivity as compared to those of the A-5 neurons. In contrast, the intensity of immunostaining with TH is similar in both neuronal groups. Bar $=20 \mu \mathrm{m}$. 

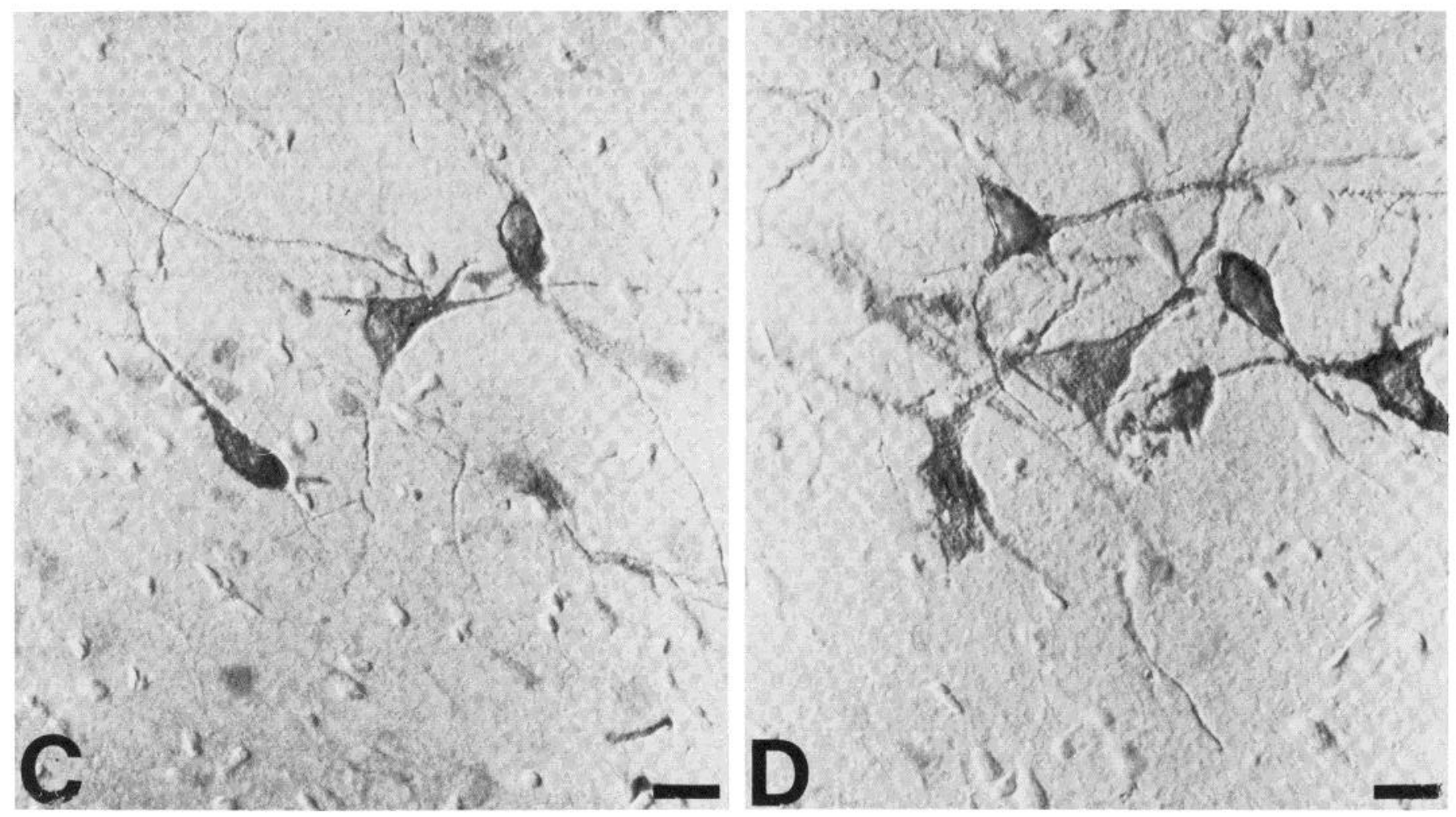

Figure 4 continued

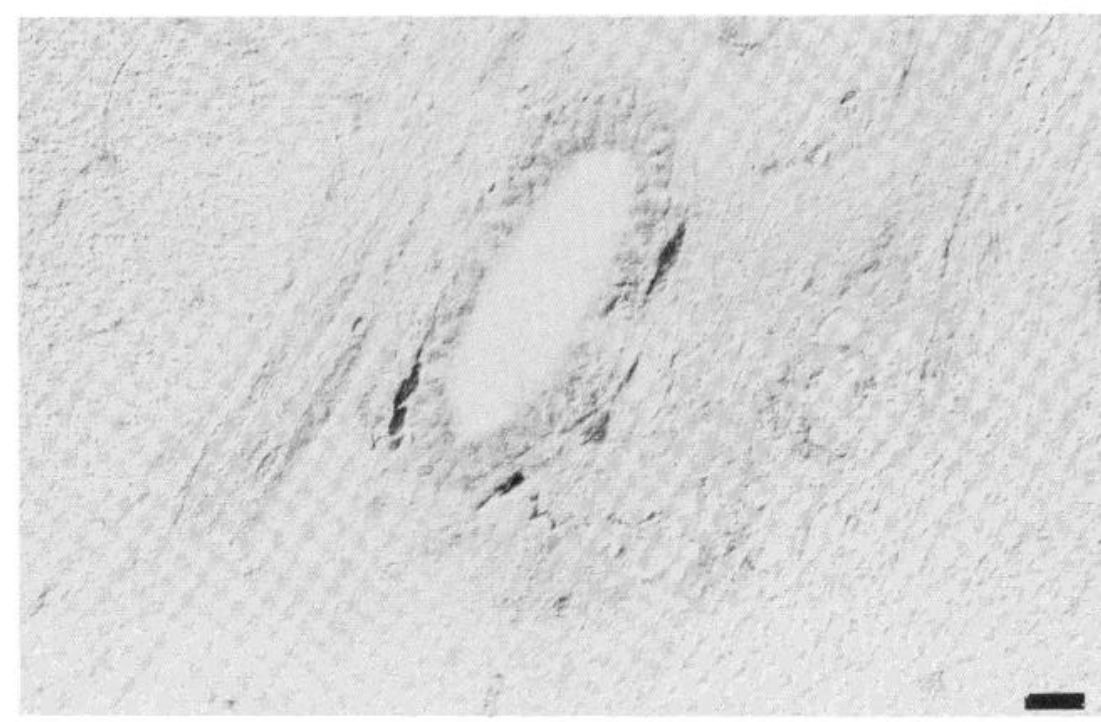

Figure 5. Immunocytochemical localization of AADC in cells and fibers of the cervical spinal cord of adult rat. Bar $=20 \mu \mathrm{m}$.

the pancreas and gut during development (Cochard et al., 1978; Teitelman et al., 1978, 1981a, b). Alternatively, some or even all of the cells in the spinal cord may persist as the scattered periventricular AADC-containing cells of newborns and adults (Jaeger et al., 1982). Whether these cells are neurons remains to be established.

In contrast to brain, where AADC is detected in neuroepithelial cells, the enzyme is not observed in migrating neural crest cells. Although these observations may indicate a difference in the timing of appearance of AADC in neuronal precursors of peripheral and central nervous system, it is also possible that the enzyme may be present in migrating neural crest cells, but at concentrations below the sensitivity of our technique. Other evidence from this study also suggests that a certain concentration of AADC molecules must be present in order to obtain a positive immunostaining reaction. Thus, in sympathetic ganglia and irain, AADC immunoreactivity is detected 1 or 2 days after the first appearance of endogenous monoamines (Olson and Sieger, 1972; Lauder and Bloom, 1974; Cochard et al., 1978).

The appearance of AADC is notochord and ventral neural tube is the first evidence that an enzyme of the monoamine biosynthetic pathway is located in these structures. The fact that the ventral neural tube-notochord complex lacks other monoamine biosynthetic enzymes raises questions about the identity of the substrate(s) of the enzymatic reaction catalyzed by AADC in these axial structures and about whether the product(s) of the reaction plays a regulatory role during 
development. It is of interest that the ventral neural tube-notochord complex, when transplanted to the proximity of premigratory neural crest cells or when placed in contact with noncatecholaminergic, autonomic neuroblasts, can promote the appearance of a catecholaminergic phenotype (Cohen 1972; Norr, 1973; Teillet et al.,
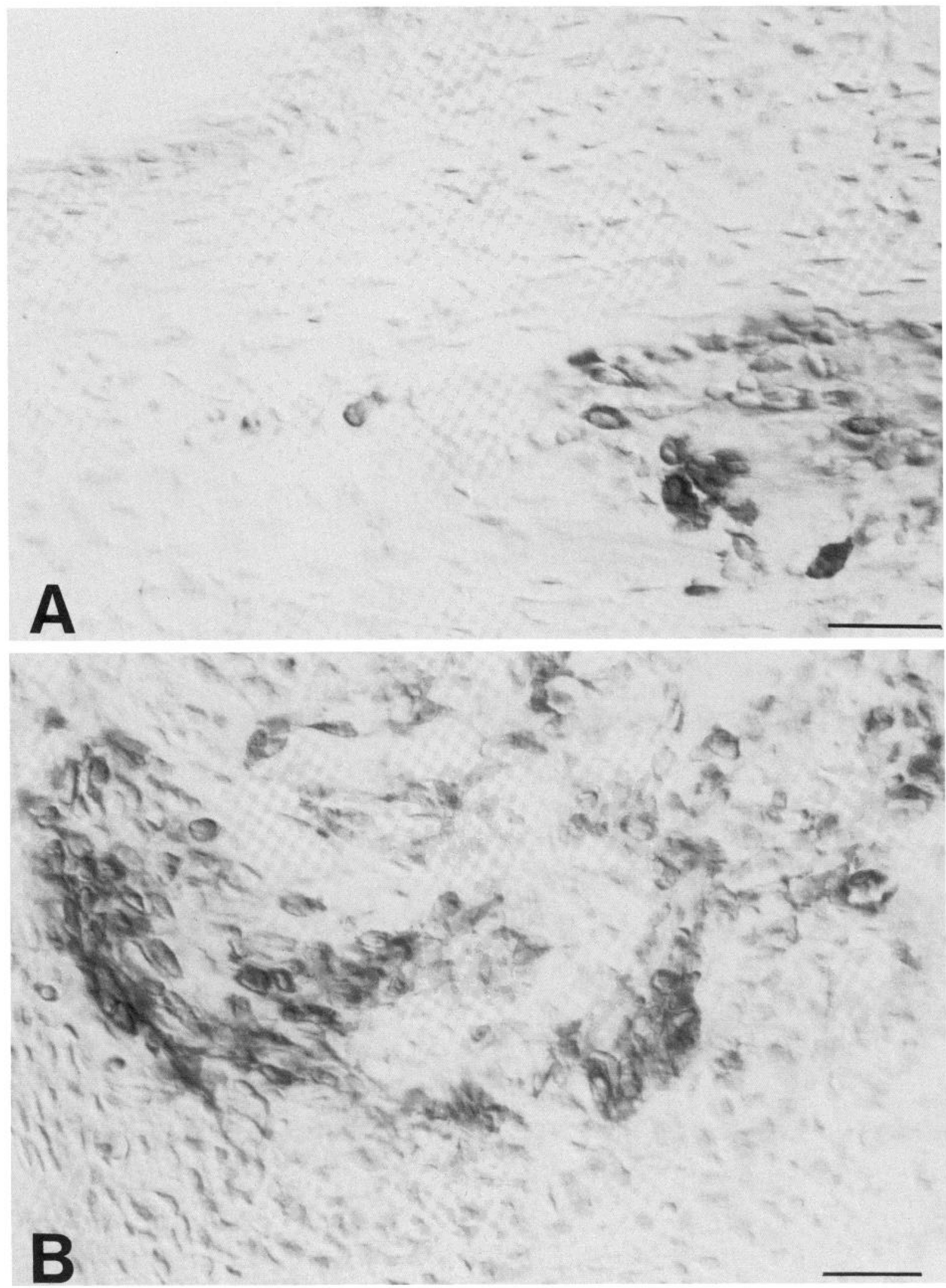

Figure 6. Immunocytochemical localization of AADC in sympathetic ganglia at day 14 of development $(A)$ and in cells of the adrenal medulla at day 16 of development $(B)$. Bar $=40 \mu \mathrm{m}$. 

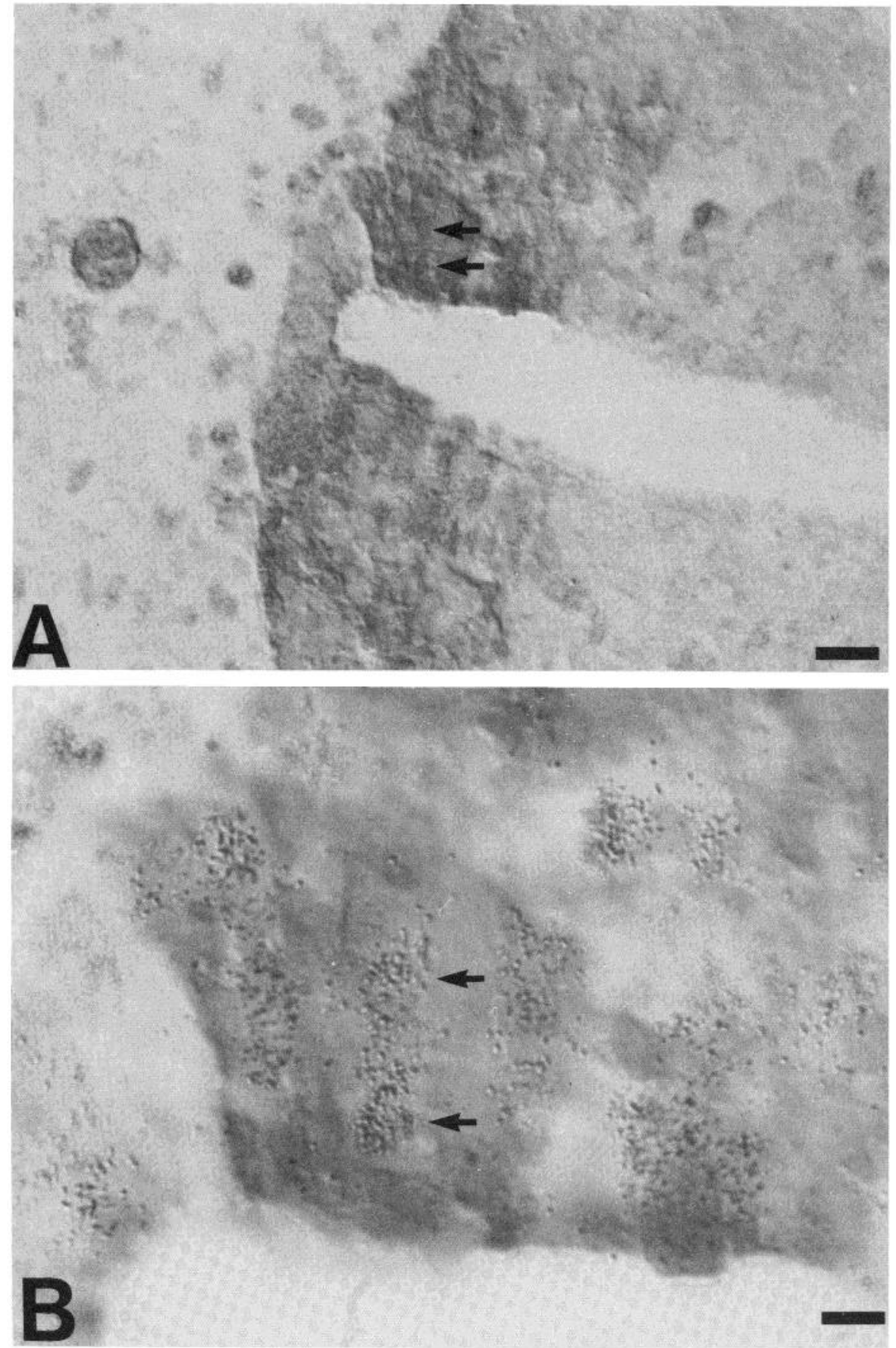

Figure 7. Photomicrographs show simultaneous localization for autoradiographic labeling by $\left[{ }^{3} \mathrm{H}\right]$ thymidine and presence of AADC immunoreactivity in the spinal cord of day 14 rat embryo. Sections were counterstained with cresyl violet. $A$, Low power photomicrograph shows the localization of AADC immunoreactivity in cells of the basal half of the neural tube. Bar $=30 \mu \mathrm{m}$. B, High magnification photomicrograph of the ventral neural tube shown in $A$. Neuroepithelial cells (arrows) are doubly labeled by $\left[{ }^{3} \mathrm{H}\right]$ thymidine and AADC immunoreactivity. Bar = $8 \mu \mathrm{m}$.
1978). In vivo, immunoreactive $\mathrm{TH}$ and $\mathrm{DBH}$ and endogenous norepinephrine appear in sympathoblasts only after the neural crest cells have migrated past the ventrolateral border of the neural tube-notochord complex (Enemar et al., 1965; Cochard et al., 1978; Teitelman et al., 1979). These findings support the possibility that the expression of a CA phenotype may be facilitated by a proximity to the ventral neural tube-notochord. Whether the appearance of such a phenotype is related to the capacity of the ventral neural tube-notochord to decarboxylate aromatic amino acids remains to be determined.

\section{References}

Allan, I. J., and D. F. Newgreen (1977) Catecholamine accu- mulation in neural crest cells and the primary sympathetic chain. Am. J. Anat. 149: 413-421.

Christenson, J. G., W. Dairman, and S. Udenfriend (1970) Preparation and properties of a homogenous aromatic LAmino Acid Decarboxylase from hog kidney. Arch. Biochem. Biophys. 141: 356-367.

Cochard, P., M. Goldstein, and I. B. Black (1978) Ontogenetic appearance and disappearance of tyrosine hydroxylase and catecholamines in rat embryo. Proc. Natl. Acad. Sci. U. S. A. 75: 2896-2990.

Cohen, A. M. (1972) Factors directing the expression of sympathetic nerve traits in cells of neural crest origin. J. Exp. Zool. 179: 167-182.

Dahlstrom, A., and Fuxe, K. (1965) Evidence for the existence of monoamine neurons in the central nervous system. Acta Physiol. Scand. 64(Suppl. 247): 1-248. 
Enemar, A., B. Falck, and B. Hakanson (1965) Observations on the appearance of norepinephrine in the sympathetic nervous system of the chick embryo. Dev. Biol. 11: 268-283.

Golden, G. S. (1973) Prenatal development of the biogenic amine system of the mouse brain. Dev. Biol. 33: 300-311.

Hanaway, J., R. McConnell, and M. Netsky (1971) Histogenesis of the substantia nigra, ventral tegmental area of Tsai and the interpeduncular nucleus. An autoradiographic study of the mesencephalon in the rat. J. Comp. Neurol. 142: 59-74.

Jaeger, C. B., G. Teitleman, T. H. Joh, V. R. Albert, D. H. Park and D. J. Reis (1982) Neurons of the rat CNS contain aromatic-L-amino acid decarboxylase but not monoamines. Science 219: 1233-1235.

Kirby, M. L., and S. A. Gilmore (1972) A fluorescent study on the ability of the notochord to synthesize and store catecholamines in early chick embryo. Anat. Rec. 173: 469-478.

Laemmli, U. K. (1970) Cleavage of structural proteins during the assembly of the head of bacteriophage T4. Nature 227: 680-685.

Lauder, J., and F. Bloom (1974) Ontogeny of monoamine neurons in the locus coeruleus, raphe nuclei and substantia nigra of the rat. I. Cell differentiation. J. Comp. Neurol. 155: 469482 .

Lauder, J. M., J. A. Wallace, and H. Krebs (1981) Roles of serotonin in neuroembryogenesis. Adv. Exp. Med. Biol. 133: 477-505.

Laurence, I. E., Jr., and H. W. Burden (1973) Catecholamines and morphogenesis of the chick embryo neural tube and notochord. Am. J. Anat. 137: 199-208.

Norr, S. C. (1973) In vitro analysis of sympathetic neuron differentiation from chick neural crest cells. Dev. Biol. 34: 16-38.

Olson, L., and A. Sieger (1972) Early prenatal ontogeny of central monoamine neurons in the rat. Fluorescence histochemical observations. Z. Anat. Entwicklungsgesch. 137: 301316.

Pearse, A. G. E., and J. M. Polak (1971) Neural crest origin of the endocrine polypeptide (APUD) cells of the gastrointestinal tract and pancreas. Gut 12: 783-788.

Rothman, T. P., L. A. Specht, M. D. Gershon, V. M. Pickel, G. Teitelman, T. H. Joh, and D. J. Reis (1980) Catecholamine biosynthetic enzymes are expressed in replicating cells of the peripheral but not the central nervous system. Proc. Natl. Acad. Sci. U. S. A. 77: 6221-6225.

Sidman, R., and I. Miale (1959) Cell proliferation and migration in the primitive ependymal zone. An autoradiographic study of histogenesis in the nervous system. Exp. Neurol. 1: 32233.

Specht, L. A., V. M. Pickel, T. H. Joh, and D. J. Reis (1981) Light microscopic immunocytochemical localization of tyrosine hydroxylase in prenatal rat brain. I. Early ontogeny. J. Comp. Neurol. 199: 233-253.

Sternberger, L. A., P. H. Hardy, J. J. Cuculis, and H. G. Meyer (1970) The unlabeled antibody enzyme method by immunohistochemistry: Preparation and properties of soluble antigen-antibody complex (horseradish peroxidase-antiperoxidase) and its use in identification of spirochetes. J. Histochem. Cytochem. 18: 315-33.

Teillet, M. A., P. Cochard, and N. M. LeDouarin (1978) Relative role of the mesenchymal tissues and of the complex neural tube-notochord on the expression of adrenergic metabolism in neural crest cells. Zoon 6: 115-122.

Teitelman, G., T. H. Joh, and D. J. Reis (1978) Transient expression of a noradrenergic phenotype in cells of the rat embryonic gut. Brain Res. 158: 229-234.

Teitelman, G., H. Baker, T. H. Joh, and D. J. Reis (1979) Appearance of catecholamine synthesizing enzymes during development of rat embryo sympathetic nervous system. Possible role of tissue environment. Proc. Natl. Acad. Sci. U. S. A. 76: 509-513.

Teitelman, G., T. H. Joh, and D. J. Reis (1981a) Transformation of catecholaminergic precursors in glucagon (A) cells in mouse embryonic pancreas. Proc. Natl. Acad. Sci. U. S. A. 78: 5225-5229.

Teitelman, G., M. D. Gershon, T. P. Rothman, T. H. Joh, and D. J. Reis (1981b) Proliferation and distribution of cells that transientally express a catecholaminergic phenotype during development in mice and rats. Dev. Biol. 86: 348-355.

Towbin, H., T. Staehelin, and J. Gordon (1979) Electrophoretic transfer of proteins from polyacrylamide gels to nitrocellulose sheets: Procedure and some applications. Proc. Natl. Acad. Sci. U. S. A. $76: 4350-4354$. 